However, during the past twenty years there has been a great increase in the science of general ecology based on the biology of reproduction, growth, moulting, digestion and excretion of the various groups that participate in the life of the soil. To provide a suitable means of presenting the work of investigators in this field, a new journal, with an international editorial board, was launched in 1964 (Revue d'Écologie et de Biologie du Sol, Tome 1, Fascicule 1, Juin 1964. Published quarterly. Pp. 1-122. Paris: Gauthier-Villars et Cie, 1964. Annual subscription 70 francs). The first volume, consisting of 3 numbers, contains 20 papers totalling 574 pages; there are 10 papers, 140 pages, in Volume 2, No. 1. Two of the papers are in English, the remainder in French.

\section{Scoring Virulence of Phytopathogenic Bacteria}

UNDER appropriate conditions, many phytopathogenic bacteria can express virulence capacities much broader than is indicated by clinical experience. For example, passage through heterologous host plants can result in 'new' virulence characteristics. A likely mechanism would be the selection by the unnatural host plant of postulated naturally occurring virulent individuals in a statistically avirulent population-such population analysis requires a "vegetable white mouse" as a device for scoring virulence. The use of excised bean pods, under carefully specified conditions, together with genetically labelled bacterial cultures, has provided M. P. Starr and D. W. Dye of the Plant Diseases Division, Department of Scientific and Industrial Research, Auckland, with reliable, sensitive and convenient virulence-scoring techniques (New Zealand Journal of Science, 8, No. 1; March 1965).

\section{Phylogeny of the Chimaeroids}

C. Patterson, writing from the British Museum, considers the Holocophali to be more closely related to arthrodires than to sharks and rays, although not descended from the very similar ptyctodont arthrodires, as Orvig and Stensiö have considered probable, but as an independent evolution from pre-arthrodiran stock (Phil. Trans. Roy. Soc., B, 249, No. 757. June 10, 1965. The Phylogeny of the Chimaeroids. Pp. 10I-219+plates 22-28. London: the Royal Society, 1965. 55s. 6d.; 8.30 dollars). The phylogeny of modern chimaeroid fishes is traced back through Mesozoic times to a Palaeozoic sub-order of the Chimaeriformes, the Menaspoidei, which possessed armour, at least to the extent of a dorsal head-shield: the balance of evidence suggests that the Chimaeriformes were derived directly from armoured ancestors with an unmodified hyoid arch, from which stock unarmoured Holocephali of the Carboniferous period, such as Helodus and Chondrenchelys, would also be derived. A fairly clear picture of the head of a Lower Carboniferous menaspoid genus, Deltoptychius, begins to emerge, partly from material previously ascribed to Oracanthus. Fossil remains of Holocephali, other than their tooth-plates, being rare, the microstructure of finspines, dermal plates and scales, and teeth provides much of the evidence. Changes in the structure of the dorsal fin-spine and in the evolution of a synchronomorial (placoid) scale from a cyclomorial form are found to be parallel to changes which took place in sharks. It is held that the Devonian ancestors of the Chimaeriformes would have possessed a dermal structure like that described as Eczematolepis (Mid-Devonian), which is not accepted here as ptyctodont. The point seems crucial, but this sort of histology is at present very much a specialist's subject. The section on tooth structure is important since it deals with part of the evidence from which the origin of teeth in vertebrates may eventually be understood. The criteria used seem justifiable, for example, presence or absence of pallial dentine, although the outer part of pallial dentine may become metaplastic and form part of the enameloid tissue. A diagram showing the supposed phylogenetic relationships would have helped to a more critical understanding of this topical problem-have the aphetohyoid, joint-necked fishes survived in the chimaeras ?-likewise a diagram showing the crown and socalled root in different durophagous fishes.

\section{Brain of the Pearly Nautilus}

Nothing has been known hitherto of the fine structure of the brain of Nautilus, and Prof. J. Z. Young's recent paper (Phil. Trans. Roy. Soc., B, 249, No. 754: The Central Nervous System of Nautilus. Pp. 1-25+plates 1-7. London: the Royal Society, 1965. 21s.; 3.15 dollars) will be of wide interest. The brain proves to be in many ways similar to, but simpler than, that of other living Cephalopods (Coleoidea), but differs from the coleoid brain in the relatively small size of the optic and large size of the olfactory lobes, and of the rhinophore: the brain is a 'nose' rather than an 'eye' brain, macrosmatic rather than microsmatic. The nerves from the funnel are shown to be connected with the lateral part of the brain, where a small 'magnocellular lobe' is to be found; those from the digital tentacles, however, lead directly into the supraoesophageal cerebral centre, which also receives the nerves from the hood. The tentacles should thus be regarded as cephalic; the name 'Cephalopoda' embodies an ancient error of interpretation. The cerebral connexion of the digital tentacles is of special interest in the light of two other papers by Prof. J. Z. Young (Phil. Trans. Roy. Soc., B, 249, No. 755: The Buccal Nervous System of Octopus. The Centres for Touch Discrimination in Octopus. Pp. 27-67+plates 8-17. London: the Royal Society, 1965. 18s.; 2.70 dollars), one of which traces elegantly the series of nerve-centres of the feeding processes in Octopus-catching the food, poisoning, triturating and swallowing it-while, in the other, the connexion and origin of the inferior frontal system of the brain of Octopus are described. This system is already known to be the centre of tactile learning and is now shown to be derived in development from the feeding centres. It is thus suggested that food-discrimination is all-important in developing the learning centres of the brain in the Cephalopoda.

International Commission on Zoological Nomenclature Notice is hereby given of the possible use by the International Commission on Zoological Nomenclature of its plenary powers in connexion with the following cases, full details of which will be found in the Bulletin of Zoological Nomenclature (22, Part 3; August 13, 1965): (1) Validation of the generic name Cacatua Vieillot, 1817 (Aves). Z.N.(S.) 1647. (2) Designation of a type-species for Anthanassa Scudder, 1875 (Insecta, Lepidoptera). Z.N.(S.) 1697. (3) Suppression of the specific name Aphelenchus steueri Stefański, 1916 (Nematoda). Z.N.(S.) 1698. (4) Validation of the generic name Amblema Rafinesque, 1820 (Lamellibranchiata). $\quad Z . N .(S) 1699$. (5) Suppression of the specific names Voluta pertusa Linnaeus, 1758, V. morio Linnaeus, 1767, V. ruffina Linnaeus, 1767, and Bulla conoidea Linnaeus, 1767 (Gastropoda). Z.N.(S.) 1700 . (6) Validation of the specific name Vespertilio yumanensis H. Allen, 1864 (Mammalia). Z.N.(S.) 1701. (7) Suppression of the generic name Trichogonia Rossmaessler, 1835 (Lamellibranchiata). $Z . N$.(S.) 1702. Any zoologist who wishes to comment on any of the foregoing cases should do so in writing to the Secretary, International Commission on Zoological Nomenclature, c/o British Museum (Natural History), Cromwell Road, London, S.W.7, before February 13, 1966.

\section{Races of Man}

THE second edition of Races of Man, by Sonia Cole, serves as a useful guide to the methods of investigation used in the differentiation of racial types (Pp. $131+13$ plates +34 figures. London: Trustees of the British Museum (Natural History), 1965. 11s. 6d.). A brief historical background is followed by descriptive chapters 